\title{
Biological invasions and natural colonisations are different - the need for invasion science
}

\author{
John R. U. Wilson 1,2, Pablo García-Díaz³, Phillip Cassey³, David M. Richardson², \\ Petr Pyšek ${ }^{4,5}$, Tim M. Blackburn ${ }^{6,7}$
}

I South African National Biodiversity Institute, Kirstenbosch Research Centre, Claremont 7735, South Africa 2 Centre for Invasion Biology, Department of Botany and Zoology, Stellenbosch University, Matieland 7602, South Africa 3 School of Biological Sciences and Centre for Conservation Science and Technology(CCoST), The University of Adelaide, North Terrace SA 5005, Australia 4 Institute of Botany, Department of Invasion Ecology, The Czech Academy of Sciences, CZ-252 43 Prühonice, Czech Republic 5 Department of Ecology, Faculty of Science, Charles University in Prague, Viničná 7, CZ-128 44 Prague, Czech Republic 6 Department of Genetics, Evolution and Environment, Centre for Biodiversity and Environment Research, University College London, Gower Street, London WC1E 6BT, UK 7 Institute of Zoology, Zoological Society of London, Regent's Park, London NW1 4RY, UK

Corresponding author:John R.U. Wilson (john.wilson2@gmail.com)

Academic editor: I. Kühn | Received 22 May 2016 | Accepted 28 June 2016 | Published 14 September 2016

Citation: Wilson JRU, García-Díaz P, Cassey P, Richardson DM, Pyšek P, Blackburn TM (2016) Biological invasions and natural colonisations are different - the need for invasion science. NeoBiota 31: 87-98. doi: 10.3897/neobiota.31.9185

\begin{abstract}
In a recent Discussion Paper, Hoffmann and Courchamp (2016) posed the question: are biological invasions and natural colonisations that different? This apparently simple question resonates at the core of the biological study of human-induced global change, and we strongly believe that the answer is yes: biological invasions and natural colonisations differ in processes and mechanisms in ways that are crucial for science, management, and policy. Invasion biology has, over time, developed into the broader transdisciplinary field of invasion science. At the heart of invasion science is the realisation that biological invasions are not just a biological phenomenon: the human dimension of invasions is a fundamental component in the social-ecological systems in which invasions need to be understood and managed.
\end{abstract}

\section{Keywords}

Invasion science, invasion biology, definitions

Copyright John R.U.Wilson et al. This is an open access article distributed under the terms of the Creative Commons Attribution License (CC BY 4.0), which permits unrestricted use, distribution, and reproduction in any medium, provided the original author and source are credited. 


\section{Something in the way they move}

Hoffmann and Courchamp (2016) argue that human-mediated extra-range dispersal does not differ in terms of processes or mechanisms from natural colonisation, but that all dispersal events sit on a broad but continuous spectrum of species movements. Their rationale is that in both human-mediated extra-range dispersal and natural colonisations, populations have to overcome the same barriers (survival, reproduction, dispersal and further range expansion), and differ only in the "inconsequential" way in which they move from the original to the novel recipient locations (using their own means versus human transportation). Hoffmann and Courchamp (2016) suggest that there are four main reasons why scientists traditionally consider human-mediated extra-range dispersal and natural colonisations separately: (i) propagule pressure is greater for human-mediated extra-range dispersal; (ii) colonisation pressure is greater for human-mediated extra-range dispersal; (iii) genetic diversity is different; and (iv) human-mediated extra-range dispersal is more likely to result in invasions which lead to mass extinctions. They then argue that these differences are not clear-cut, and that even if such differences exist, they are differences of degree (e.g. rate or magnitude) rather than of kind. They conclude that humanmediated extra-range dispersal events "do not represent a distinctly different or change in process, just an acceleration of the colonisation process through multiple mechanisms".

We agree with Hoffmann and Courchamp (2016) that there is much to be learnt by invasion scientists from studying processes of natural colonisation (and vice versa; ecologists researching colonisation processes may learn from developments in invasion science). The same mathematical and theoretical models of dispersal and establishment can sometimes apply. For example, the concept of hierarchical filters for delineating pools of native species in studies of assemblages of natural communities resembles the concept and stages of the invasion pathway (Blackburn et al. 2011; Karger et al. 2016). In comparing when and where particular models are useful, and how parameter values differ, there can be useful insights for understanding and management.

Nevertheless, we disagree with the rest of their thesis - and note that the arguments made have already been well identified, characterised, and repeatedly rebutted (Cassey et al. 2005; Ricciardi 2007; Richardson and Ricciardi 2013). In particular, the dynamics and processes of dispersal leading to biological invasions are often quantitatively and qualitatively different from dispersal leading to natural colonisation (Wilson et al. 2009a; Wilson et al. 2009b). Wilson et al. (2009b) identified seven key properties of dispersal pathways: propagule pressure, genetic diversity, potential for simultaneous movement of coevolved species, selectivity of what is moved, the duration of the dispersal opportunities, evolutionary distance (time since divergence) between species in the original and new ranges, and the level of human assistance provided in spread and establishment. Hoffmann and Courchamp (2016) examined three of these, but all aspects are important (and there may be others). By focusing on the properties of different types of dispersal it becomes clear that human-mediated extra-range dispersal often varies very substantially in both kind and degree from natural colonisation. There is something in the way humans move species that moves them like no others. 


\section{Here, there and everywhere}

In some cases, natural and human-mediated extra-range dispersal are qualitatively similar. Hoffmann and Courchamp (2016) provide three examples of this (tsunamis, rangeshifts due to climate changes, and Lessepsian migration). Wilson et al. (2009b) categorised such dispersal events as extreme long-distance dispersal, leading-edge dispersal, and corridor respectively. However, there are other types of dispersal that simply never happened before humans evolved and started moving around the world, termed mass dispersal and cultivation (Fig. 1, Wilson et al. 2009b). These pathways are now major drivers of invasions. Such dispersal often results in the movement of massive numbers of individuals of species, that never would have dispersed naturally, to locations where they are provided substantial resources that facilitate establishment and invasion.

Hoffmann and Courchamp (2016) use examples of the colonisation of volcanic islands to argue that organisms move regardless of humans. This is true but disingenuous. Most individuals of most animal species move some distance in their lifetimes, but those distances are constrained at a range of scales. Thus, we can study activity schedules, home ranges, migration routes, and geographic ranges as more or less real entities. At the broadest of these scales, the presence of biogeographic regions shows that there are fundamental barriers to the spread of species that are not normally breached even over evolutionary timescales. If dispersal was not limiting why can we distinguish Gondwanan and Laurasian taxa? The existence of examples like the Great American Interchange (cited by Hoffmann and Courchamp (2016)) simply serve to highlight how rare are major faunal exchanges across such barriers. Biogeographic breaks are hugely important. Some groups might be less restricted by biogeographical features (particularly those groups that can form part of the aerial plankton), but other groups (in particular soil organisms) can be profoundly affected, with the resulting biogeographical breaks hard to distinguish. This is why species that cross such biogeographical breaks (either naturally or through human-mediated means) can occasionally have profound impacts.

The transportation of alien species by human agency across biogeographic barriers that have never historically been crossed before is essentially a daily occurrence now (Seebens et al. 2016). No passerine birds of European origin had colonised New Zealand over the tens of millions of years of the archipelago's independent existence, but now there is a thriving assemblage of such species that has developed in New Zealand over the last 150 years thanks to human intervention (Duncan, Blackburn \& Cassey 2006). The pond slider (Trachemys scripta) is native to the southeast of the U.S.A. and Mexico. The maximum recorded dispersal distance of nesting females is $1.4 \mathrm{~km}$ (Steen et al. 2012; Garcia-Diaz et al. 2015). Yet, since the 1960s, the species has been introduced to 77 countries around the world, establishing self-sustaining populations in 36 countries (i.e. a dispersal distance of $-20,000 \mathrm{~km}$ ). Consider the alien fauna and flora of the region where you live. Which, if any, of these organisms could have arrived by natural colonisation? Are these simply differences in rates? Notwithstanding events like the Tohoku tsunami, to view human-mediated extra-range dispersal as simply a difference of degree from natural colonisation is to stretch the concept of degree beyond breaking point. 

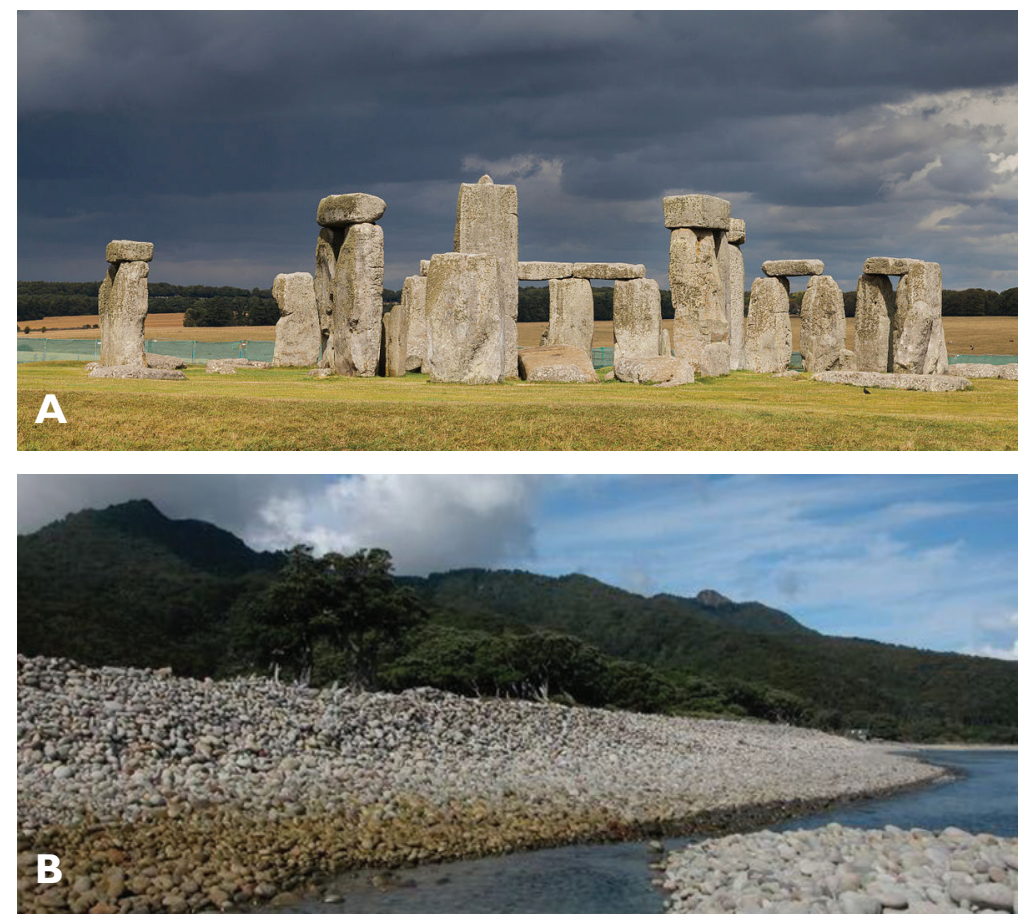

Figure I. Human-mediated dispersal and natural colonisation: are they that different? A Stonehenge and B a rocky shore were both created by rolling stones, but they are quite different in origin and these differences are important. A is courtesy of Diego Delso, under the CC BY-SA 4.0 licence, https://commons. wikimedia.org/w/index.php?curid=35323153); $\mathbf{B}$ is courtesy of Tim Blackburn.

Even in instances where the differences between natural colonisation and humanmediated extra-range dispersal appear qualitatively similar, the degree can be important. Mass extinctions are "just" extinctions that occur at a higher rate; conservation biology is really only the population biology of species with small or declining populations; epidemiology is "just" the population biology of disease-causing organisms; medicine is "just" the diagnosis, treatment, and prevention of disease in one particular primate species. Are medical doctors basically specialised vets? That they are not is because differences in degree have important implications for the causes and consequences of the processes under investigation. For example, small populations are affected by stochastic events in ways that large populations are not, justifying the distinction between conservation and population biology. Differences of degree also matter because natural systems are frequently non-linear, such that increases in some parameters can lead to step changes in their responses. This is why we worry about humanity's contribution to atmospheric $\mathrm{CO}_{2}$, even though this is a natural (and naturally varying) component of the atmosphere, and the concentrations of $\mathrm{CO}_{2}$ in the atmosphere are well within the levels seen over geological time scales. As a further example, Gaston et al. (2003) compared natural and alien colonisations to Gough Island. Gough has accumulated 28 
indigenous pterygote insect species over its 2-3 million year existence, but a further 71 pterygote species have been added to its insect fauna in the 325 years since humans first landed. Thus, the rate of accumulation on Gough Island has increased by $2-3$ orders of magnitude as a result of human transport. This does not represent an acceleration, but rather a step change in species accumulation, akin to the difference between rates of background and mass extinctions (Pimm et al. 2014). Degree matters.

Finally, one of the main reasons such types of dispersal need to be distinguished from natural colonisation is what happens post-arrival. While conceptually the same barriers are present, the resources provided for establishment mean that some barriers are rendered inconsequential. How and where individuals arrive matters a great deal. For example, every year dozens of geese, ducks, raptors, rails, gulls, terns, pigeons, cuckoos, shorebirds, flycatchers, vireos, thrushes, warblers, sparrows, orioles, and other North American bird species arrive in the UK to the immense excitement of birdwatchers. Yet, since naturalists recognised the phenomenon in the early $19^{\text {th }}$ century, none of these species has colonised and established permanent populations in the UK. In contrast, over the same period, the UK has gained well-established breeding populations of at least two North American species (Canada goose Branta canadensis and ruddy duck Oxyura jamaicensis) as a result of deliberate introductions. The largely stochastic and widely distributed arrival of small numbers of (probably exhausted) birds is extremely unlikely to have the same establishment outcome as concentrated and oftentimes intentional introductions of large numbers of well-provisioned individuals.

\section{All down the line}

An important emerging lesson in invasion science is that the manner by which species are introduced has long-lasting consequences on invasion trajectories (Donaldson et al. 2014). The invasion process (progression along the introduction-naturalisationinvasion continuum) is different for organisms introduced by humans to the processes associated with establishment and colonisation of organisms that arrive without human assistance (Hulme et al. 2016). Invasions differ from natural colonisation in biogeographical, ecological and anthropogenic dimensions (Rejmánek 2000), and historically too little research has focussed on how species are moved around (Puth and Post 2005). This is changing, and there has been a recent focus on introduction pathways (Essl et al. 2015a; Cope et al. 2016; Faulkner et al. 2016; Ricciardi 2016; Seebens et al. 2016). Moreover, species that have arrived in a new region through human-mediated extra-range dispersal or through natural colonisation can, of course, also co-opt the same dispersal pathways once in a region. This has been acknowledged many times before (e.g. Richardson and Pyšek 2006; Hulme et al. 2008) and is an important part of the reasoning behind the unified framework for biological invasions proposed by Blackburn et al. (2011). This is why there is an important distinction between transport and introduction in this framework, a distinction which is lost in Hoffmann and Courchamp's unhelpful edits to it. 
The terminology of biological invasions that was proposed for plants in 2000 and generalised across taxa a decade later (Richardson et al. 2000; Blackburn et al. 2011) has been accepted by the majority of researchers because it is useful. The scheme has provided the basis for several recent large scale syntheses of the macroecology of invasions in a variety taxonomic groups (e.g. Essl et al. 2015b for bryophytes, Capinha et al. 2015 for gastropods, and van Kleunen et al. 2015 for plants). Such applications highlight strengths and weaknesses, and we welcome such tests of the scheme. As noted by Hoffmann and Courchamp (2016), there is more work to be done on the coding of the different stages proposed in the scheme by (Blackburn et al. 2011), and in particular we need recommendations on how to apply it in practice (Wilson et al. 2014). However, by failing to appreciate the importance of introduction dynamics, the revisions proposed by Hoffmann and Courchamp (2016) reduce the scheme's general applicability rather than increase it.

Hoffmann and Courchamp (2016) argue for more work on impacts, and we strongly support this call. Despite recent efforts to provide robust insights (Vilà et al. 2011; Pyšek et al. 2012), data on impacts are rare (be they by native or alien species). More information is urgently needed both observational and experimental (Kumschick et al. 2015). However, what data there are strongly suggest that natives are significantly less likely than aliens to be problematic for local ecosystems (Simberloff et al. 2012; Paolucci, MacIsaac \& Ricciardi 2013; Buckley and Catford 2016), and that aliens can be extremely problematic. Hoffmann \& Courchamp's suggestion that "with the (dramatic) exception of a few mammals, ants and pathogens,...there is little evidence that exotic species induce species extinctions" flies in the face of the abundant evidence that aliens are a major driver of native species extinction, including alien molluscs, fish and reptiles (Pyšek et al. 2016) - aliens have been the major cause of vertebrate extinctions over the last 500 years (Bellard, Cassey \& Blackburn 2016). Even were that not the case, population-level declines (see Pyšek et al. 2016 for examples), introgression and losses of genetic diversity (Munoz-Fuentes et al. 2007), and the loss of community-level identity (i.e. homogenisation; Lockwood and McKinney 2001) are all crucial, and increasingly well documented, impacts of biological invasions. Impact should not be measured solely by species-level extinctions, but by a suite of measure of impacts on people, places and biodiversity. Standardised schemes for categorising environmental impact designed for invasive species (Blackburn et al. 2014) can potentially be adapted for native species, and proposed schemes to classify socio-economic impacts of alien taxa hold much promise for conservation more generally. But understanding where a taxon has come from, and in particular whether it is invasive or not, is often essential to understanding why these impacts occur and how they can be managed.

There are some excellent schemes that provided a basis for how to determine if invasive taxa are different from other taxa (van Kleunen et al. 2010), but in our view, efforts to partition off the "real biological" signal from the influence of humans is not only impractical, but at heart fails to recognise that invasions are intrinsically a human 
product. Understanding the processes and mechanisms of biological invasions requires not just ecological studies, but an understanding of how humans move organisms to their new ranges, how they interact with them on arrival, and how they move them around their new ranges. This is why invasion biology has grown and developed into invasion science (Richardson 2011).

\section{No expectations?}

Hoffmann and Courchamp (2016) make an attempt at reductio ad absurdum with the question: are humans an "invasive" species or not. We agree that this discussion is mostly extraneous semantics, albeit one that can lead to some very disturbing conclusions, but it highlights the essential problem. We cannot extricate humans from invasions or invasions from humans. Invasions provide not only valuable test cases for ecologists, evolutionary biologists, and physiologists, but also important insights for our understanding of humans and their interactions with the environment. Hoffmann and Courchamp (2016) argue that if we want to understand the ecological process of dispersal, then invasion ecology should do more to productively engage with scientists in other fields. That is exactly what invasion ecologists do (in fact most of us learnt our trades in other fields before turning to invasion science). There are plenty of examples of transdisciplinary research on biological invasions produced by collaborations between invasions ecologists and social scientists, economists and evolutionary ecologists, decision scientists and mathematical biologists (Lockwood, Hoopes \& Marchetti 2013). These collaborations only serve to highlight the pivotal role of humans.

Neither can we observe any evidence within the field of invasion science of the isolation of researchers working on different taxa. This may have been true twenty years ago, but the last decade has seen rapid development, as data from a broader range of taxa and standardised analytical and conceptual frameworks became available (Hulme et al. 2008; Walther et al. 2009; Blackburn et al. 2014; Essl et al. 2015a). The result has been a series of multi-author collaborations comparing invasion patterns in multiple taxa (Lockwood, Cassey \& Blackburn 2005; Pyšek et al. 2010; Vilà et al. 2010; Essl et al. 2011; Aronson et al. 2014; Kumschick et al. 2015).

To conclude, biological invasions and natural colonisations are very often different; sometimes this matters, sometimes it does not. We should clearly focus more on processes and mechanisms, but the null expectation should be that biological invasions are qualitatively and quantitatively different from natural colonisation. Indeed, that is why we are moving from a Holocene period characterised by biogeographic regions with a rich global texture of unique and distinctive biotas, into an Anthropocene characterised by homogenisation, extinction and other massive global changes (Lewis and Maslin 2015). If future civilisations will be able to recognise this change in the geological record, we should be able to recognise it while it goes on around us each and every day of the year. 


\section{Acknowledgements}

The DST-NRF Centre of Excellence for Invasion Biology provided support to JRUW and DMR. We also thank Ingolf Kuehn and Anthony Ricciardi for constructive comments. PP was supported by long-term research development project RVO 67985939 (The Czech Academy of Sciences), project no. 14-36079G, Centre of Excellence PLADIAS (Czech Science Foundation) and acknowledges support by Praemium Academiae award from The Czech Academy of Sciences.

\section{References}

Aronson MFJ, La Sorte FA, Nilon CH, Katti M, Goddard MA, Lepczyk CA, Warren PS, Williams NSG, Cilliers S, Clarkson B, Dobbs C, Dolan R, Hedblom M, Klotz S, Kooijmans JL, Kühn I, MacGregor-Fors I, McDonnell M, Mortberg U, Pyšek P, Siebert S, Sushinsky J, Werner P, Winter M (2014) A global analysis of the impacts of urbanization on bird and plant diversity reveals key anthropogenic drivers. Proceedings of the Royal Society BBiological Sciences 281: 8. doi: 10.1098/rspb.2013.3330

Bellard C, Cassey P, Blackburn TM (2016) Alien species as a driver of recent extinctions. Biology Letters 12: 4. doi: 10.1098/rsbl.2015.0623

Blackburn TM, Essl F, Evans T, Hulme PE, Jeschke JM, Kühn I, Kumschick S, Marková Z, Mrugała A, Nentwig W, Pergl J, Pyšek P, Rabitsch W, Ricciardi A, Richardson DM, Sendek A, Vilà M, Wilson JRU, Winter M, Genovesi P, Bacher S (2014) A unified classification of alien species based on the magnitude of their environmental impacts. PLoS Biology 12: e1001850. doi: 10.1371/journal.pbio. 1001850

Blackburn TM, Pyšek P, Bacher S, Carlton JT, Duncan RP, Jarošík V, Wilson JRU, Richardson DM (2011) A proposed unified framework for biological invasions. Trends in Ecology \& Evolution 26: 333-339. doi: 10.1016/j.tree.2011.03.023

Buckley YM, Catford J (2016) Does the biogeographic origin of species matter? Ecological effects of native and non-native species and the use of origin to guide management. Journal of Ecology 104: 4-17. doi: 10.1111/1365-2745.12501

Capinha C, Essl F, Seebens H, Moser D, Pereira HM (2015) The dispersal of alien species redefines biogeography in the Anthropocene. Science 348: 1248-1251. doi: 10.1126/science.aaa8913

Cassey P, Blackburn TM, Duncan RP, Chown SL (2005) Concerning invasive species: Reply to Brown and Sax. Austral Ecology, 30: 475-480. doi: 10.1111/j.1442-9993.2005.01505.x

Cope RC, Ross JV, Wittmann TA, Prowse TAA, Cassey P (2016) Integrative analysis of the physical transport network into Australia. PLoS ONE 11: 16. doi: 10.1371/journal. pone. 0148831

Donaldson JE, Hui C, Richardson DM, Robertson MP, Webber BL, Wilson JRU (2014) Invasion trajectory of alien trees: the role of introduction pathway and planting history. Global Change Biology 20: 1527-1537. doi: 10.1111/gcb.12486

Duncan RP, Blackburn TM, Cassey P (2006) Factors affecting the release, establishment and spread of introduced birds in New Zealand. In: Allen RB, Lee WG (Eds) Biological Inva- 
sions in New Zealand. Springer-Verlag, Berlin, Heidelberg, 137-154. doi: 10.1007/3-54030023-6

Essl F, Bacher S, Blackburn TM, Booy O, Brundu G, Brunel S, Cardoso A-C, Eschen R, Gallardo B, Galil B, García-Berthou E, Genovesi P, Groom Q, Harrower C, Hulme PE, Katsanevakis S, Kenis M, Kühn I, Kumschick S, Martinou AF, Nentwig W, O’Flynn C, Pagad S, Pergl J, Pyšek P, Rabitsch W, Richardson DM, Roques A, Roy HE, Scalera R, Schindler S, Seebens H, Vanderhoeven S, Vilà M, Wilson JRU, Zenetos A, Jeschke JM (2015a) Crossing frontiers in tackling pathways of biological invasions. Bioscience 65: 769-782. doi: 10.1093/biosci/biv082

Essl F, Dullinger S, Moser D, Steinbauer K, Mang T (2015b) Macroecology of global bryophyte invasions at different invasion stages. Ecography 38: 488-498. doi: 10.1111/ecog.00905

Essl F, Dullinger S, Rabitsch W, Hulme PE, Hulber K, Jarošík V, Kleinbauer I, Krausmann F, Kuhn I, Nentwig W, Vilà M, Genovesi P, Gherardi F, Desprez-Loustau ML, Roques A, Pyšek P (2011) Socioeconomic legacy yields an invasion debt. Proceedings of the National Academy of Sciences of the United States of America 108: 203-207. doi: 10.1073/ pnas. 1011728108

Faulkner KT, Robertson MP, Rouget M, Wilson JRU (2016) Understanding and managing the introduction pathways of alien taxa: South Africa as a case study. Biological Invasions 18: 73-87. doi: 10.1007/s10530-015-0990-4

Garcia-Diaz P, Ross JV, Ayres C, Cassey P (2015) Understanding the biological invasion risk posed by the global wildlife trade: propagule pressure drives the introduction and establishment of Nearctic turtles. Global Change Biology 21: 1078-1091. doi: 10.1111/gcb.12790

Gaston KJ, Jones AG, Hanel C, Chown SL (2003) Rates of species introduction to a remote oceanic island. Proceedings of the Royal Society B-Biological Sciences 270: 1091-1098. doi: $10.1098 /$ rspb.2003.2332

Hoffmann BD, Courchamp F (2016) Biological invasions and natural colonisations: are they that different? Neobiota 29: 1-14. doi: 10.3897/neobiota.29.6959

Hulme PE, Bacher S, Kenis M, Klotz S, Kühn I, Minchin D, Nentwig W, Olenin S, Panov V, Pergl J, Pyšek P, Roques A, Sol D, Solarz W, Vilà M (2008) Grasping at the routes of biological invasions: a framework for integrating pathways into policy. Journal of Applied Ecology 45: 403-414. doi: 10.1111/j.1365-2664.2007.01442.x

Hulme PE, Bacher S, Kenis M, Kühn I, Pergl J, Pyšek P, Roques A, Vilà M (2016) Blurring alien introduction pathways risks losing the focus on invasive species policy. Conservation Letters. doi: $10.1111 /$ conl.12262

Karger DN, Cord AF, Kessler M, Kreft H, Kuehn I, Pompe S, Sandel B, Cabral JS, Smith AB, Svenning JC, Tuomisto H, Weigelt P, Wesche K (2016) Delineating probabilistic species pools in ecology and biogeography. Global Ecology and Biogeography 25: 489-501. doi: 10.1111/geb.12422

Kumschick S, Gaertner M, Vilà M, Essl F, Jeschke JM, Pyšek P, Ricciardi A, Bacher S, Blackburn TM, Dick JTA, Evans T, Hulme PE, Kühn I, Mrugala A, Pergl J, Rabitsch W, Richardson DM, Sendek A, Winter M (2015) Ecological impacts of alien species: Quantification, scope, caveats, and recommendations. Bioscience 65: 55-63. doi: 10.1093/biosci/biu 193

Lewis SL, Maslin MA (2015) Defining the Anthropocene. Nature 519: 171-180. doi: 10.1038/ nature 14258 
Lockwood JL, Cassey P, Blackburn T (2005) The role of propagule pressure in explaining species invasions. Trends in Ecology and Evolution 20: 223-228. doi: 10.1016/j.tree.2005.02.004 Lockwood JL, McKinney ML (2001) Biotic Homogenization. Kluwer, New York, 298 pp. doi: $10.1007 / 978-1-4615-1261-5$

Munoz-Fuentes V, Vilà C, Green AJ, Negro JJ, Sorenson MD (2007) Hybridization between white-headed ducks and introduced ruddy ducks in Spain. Molecular Ecology 16: 629638. doi: 10.1111/j.1365-294X.2006.03170.x

Paolucci EM, MacIsaac HJ, Ricciardi A (2013) Origin matters: alien consumers inflict greater damage on prey populations than do native consumers. Diversity and Distributions 19: 988-995. doi: 10.1111/ddi.12073

Pimm SL, Jenkins CN, Abell R, Brooks TM, Gittleman JL, Joppa LN, Raven PH, Roberts CM, Sexton JO (2014) The biodiversity of species and their rates of extinction, distribution, and protection. Science 344: 1246752. doi: 10.1126/science.1246752

Puth LM, Post DM (2005) Studying invasion: have we missed the boat? Ecology Letters 8: 715-721. doi: 10.1111/j.1461-0248.2005.00774.x

Pyšek P, Bacher S, Chytrý M, Jarošík V, Wild J, Celesti-Grapow L, Gasso N, Kenis M, Lambdon PW, Nentwig W, Pergl J, Roques A, Sádlo J, Solarz W, Vilá M, Hulme PE (2010) Contrasting patterns in the invasions of European terrestrial and freshwater habitats by alien plants, insects and vertebrates. Global Ecology and Biogeography 19: 317-331. doi: 10.1111/j.1466-8238.2009.00514.x

Pyšek P, Blackburn TM, Garcia-Berthou E, Perglová I, Rabitsch W (2016) Displacement and local extinction of native and endemic species. In: Vilà M, Hulme PE (Eds) Impact of Biological Invasions on Ecosystem Services. Springer, Berlin.

Pyšek P, Jarošík V, Hulme PE, Küehn I, Wild J, Arianoutsou M, Bacher S, Chiron F, Didžiulis V, Essl F, Genovesi P, Gherardi F, Hejda M, Kark S, Lambdon PW, Desprez-Loustau ML, Nentwig W, Pergl J, Poboljšaj K, Rabitsch W, Roques A, Roy DB, Shirley S, Solarz W, Vilà M, Winter M (2010) Disentangling the role of environmental and human pressures on biological invasions across Europe. Proceedings of the National Academy of Sciences of the United States of America 107: 12157-12162. doi: 10.1073/pnas.1002314107

Pyšek P, Jarošík V, Hulme PE, Pergl J, Hejda M, Schaffner U, Vilà M (2012) A global assessment of invasive plant impacts on resident species, communities and ecosystems: the interaction of impact measures, invading species' traits and environment. Global Change Biology 18: 1725-1737. doi: 10.1111/j.1365-2486.2011.02636.x

Rejmánek M (2000) Invasive plants: approaches and predictions. Austral Ecology 25: 497506. doi: 10.1046/j.1442-9993.2000.01080.x

Ricciardi A (2007) Are modern biological invasions an unprecedented form of global change? Conservation Biology 21: 329-336. doi: 10.1111/j.1523-1739.2006.00615.x

Ricciardi A (2016) Tracking marine alien species by ship movements. Proceedings of the National Academy of Sciences of the United States of America 113: 5470-5471. doi: $10.1073 /$ pnas. 1605152113

Richardson DM (2011) Invasion science: The roads travelled and the roads ahead. In: Richardson DM (Ed.) Fifty Years of Invasion Ecology: The Legacy of Charles Elton. WileyBlackwell, Malden, 397-407. 
Richardson DM, Pyšek P (2006) Plant invasions: merging the concepts of species invasiveness and community invasibility. Progress in Physical Geography 30: 409-431. doi: 10.1191/0309133306pp490pr

Richardson DM, Pyšek P, Rejmánek M, Barbour MG, Panetta FD, West CJ (2000) Naturalization and invasion of alien plants: concepts and definitions. Diversity and Distributions 6: 93-107. doi: 10.1046/j.1472-4642.2000.00083.x

Richardson DM, Ricciardi A (2013) Misleading criticisms of invasion science: a field guide. Diversity and Distributions 19: 1461-1467. doi: 10.1111/ddi.12150

Seebens H, Schwartz N, Schupp PJ, Blasius B (2016) Predicting the spread of marine species introduced by global shipping. Proceedings of the National Academy of Sciences of the United States of America 113: 5646-5651. doi: 10.1073/pnas.1524427113

Simberloff D, Souza L, Nunez MA, Barrios-Garcia MN, Bunn W (2012) The natives are restless, but not often and mostly when disturbed. Ecology 93: 598-607. doi: 10.1890/11-1232.1

Steen DA, Gibbs JP, Buhlmann KA, Carr JL, Compton BW, Congdon JD, Doody JS, Godwin JC, Holcomb KL, Jackson DR, Janzen FJ, Johnson G, Jones MT, Lamer JT, Langen TA, Plummer MV, Rowe JW, Saumure RA, Tucker JK, Wilson DS (2012) Terrestrial habitat requirements of nesting freshwater turtles. Biological Conservation 150: 121-128. doi: 10.1016/j.biocon.2012.03.012

van Kleunen M, Dawson W, Essl F, Pergl J, Winter M, Weber E, Kreft H, Weigelt P, Kartesz J, Nishino M, Antonova LA, Barcelona JF, Cabezas FJ, Cardenas D, Cardenas-Toro J, Castano N, Chacon E, Chatelain C, Ebel AL, Figueiredo E, Fuentes N, Groom QJ, Henderson L, Inderjit, Kupriyanov A, Masciadri S, Meerman J, Morozova O, Moser D, Nickrent DL, Patzelt A, Pelser PB, Baptiste MP, Poopath M, Schulze M, Seebens H, Shu W, Thomas J, Velayos M, Wieringa JJ, Pyšek P (2015) Global exchange and accumulation of non-native plants. Nature 525: 100-103. doi: 10.1038/nature14910

van Kleunen M, Dawson W, Schlaepfer D, Jeschke JM, Fischer M (2010) Are invaders different? A conceptual framework of comparative approaches for assessing determinants of invasiveness. Ecology Letters 13: 947-958. doi: 10.1111/j.1461-0248.2010.01503.x

Vilà M, Basnou C, Pyšek P, Josefsson M, Genovesi P, Gollasch S, Nentwig W, Olenin S, Roques A, Roy D, Hulme PE, Andriopoulos P, Arianoutsou M, Augustin S, Bacher S, Bazos I, Bretagnolle F, Chiron F, Clergeau P, Cochard PO, Cocquempot C, Coeur d'Acier A, David M, Delipetrou P, Desprez-Loustau ML, Didžiulis V, Dorkeld F, Essl F, Galil BS, Gasquez J, Georghiou K, Hejda M, Jarošík V, Kark S, Kokkoris I, Kühn I, Lambdon PW, Lopez-Vaamonde C, Marcer A, Migeon A, McLoughlin M, Minchin D, Navajas M, Panov VE, Pascal M, Pergl J, Perglová I, Pino J, Poboljšaj K, Rabitsch W, Rasplus JY, Sauvard D, Scalera R, Sedláček O, Shirley S, Winter M, Yannitsaros A, Yart A, Zagatti P, Zikos A, Partners D (2010) How well do we understand the impacts of alien species on ecosystem services? A pan-European, cross-taxa assessment. Frontiers in Ecology and the Environment 8: 135-144. doi: 10.1890/080083

Vilà M, Espinar JL, Hejda M, Hulme PE, Jarošík V, Maron JL, Pergl J, Schaffner U, Sun Y, Pyšek P (2011) Ecological impacts of invasive alien plants: a meta-analysis of their effects on species, communities and ecosystems. Ecology Letters 14: 702-708. doi: 10.1111/j.14610248.2011.01628.x 
Walther GR, Roques A, Hulme PE, Sykes MT, Pyšek P, Kühn I, Zobel M, Bacher S, BottaDukát Z, Bugmann H, Czucz B, Dauber J, Hickler T, Jarošík V, Kenis M, Klotz S, Minchin D, Moora M, Nentwig W, Ott J, Panov VE, Reineking B, Robinet C, Semenchenko V, Solarz W, Thuiller W, Vilà M, Vohland K, Settele J (2009) Alien species in a warmer world: risks and opportunities. Trends in Ecology \& Evolution 24: 686-693. doi: 10.1016/j. tree.2009.06.008

Wilson JRU, Caplat P, Dickie I, Hui C, Maxwell BD, Nuñez MA, Pauchard A, Rejmánek M, Richardson DM, Robertson MP, Spear D, Webber BL, van Wilgen BW, Zenni RD (2014) A standardized set of metrics to assess and monitor tree invasions. Biological Invasions 16: 535-551. doi: 10.1007/s10530-013-0605-x

Wilson JRU, Dormontt EE, Prentis PJ, Lowe AJ, Richardson DM (2009a) Biogeographic concepts define invasion biology. Trends in Ecology \& Evolution 24: 586. doi: 10.1016/j. tree.2009.07.004

Wilson JRU, Dormontt EE, Prentis PJ, Lowe AJ, Richardson DM (2009b) Something in the way you move: dispersal pathways affect invasion success. Trends in Ecology \& Evolution 24: 136-144. doi: 10.1016/j.tree.2008.10.007 